\title{
A meteorological phænomenon
}

\section{Henry Hennessy}

To cite this article: Henry Hennessy (1844) A meteorological phænomenon, Philosophical Magazine Series 3, 24:158, 238-239, DOI: 10.1080/14786444408644845

To link to this article: http://dx.doi.org/10.1080/14786444408644845

$$
\text { 册 Published online: } 30 \text { Apr } 2009 .
$$

6 Submit your article to this journal $\pi$

LII Article views: 2

Q View related articles $\asymp$ 
It appears from this analysis that beaumontite should be classed with the zeolites, and that it contains more silica than any one hitherto described; it is undoubtedly to this circumstance that its resistance to acids is owing, and also its hardness, which is nearly equal to that of phosphate of lime.-Ann. de Ch. et de Phys., Decembre 1843.

\section{DESCRIPTION AND ANALYSIS OF SISMONDINE (A NEW MINERAL). BY M. A. DELESSE.}

This substance is found at St. Marcel, and the name was given to it in honour of M. Sismonda, Professor in the University of Turin, and author of the geological map of Piedmont.

Its characters are, that it is of a deep green colour, possessing much splendour, it cleaves readily and reflects the light brilliantly; it is brittle and easily powdered, the colour of the powder is a bright grayish green. It does not affect the magnet, either before or after calcination. It scratches glass, but is scratched by steel; its density is 3.565 ; the crystalline form of this mineral could not be determined.

This mineral occurs imbedded in a kind of slaty chlorite, and is accompanied with red dodecahedral garnets and titaniferous iron, the fracture of which resembles plumbago, and the powder is perfectly black.

When heated in a glass tube sismondine yields water, but it requires to be strongly heated to produce this effect; the water is not acid, nor does it act on the tube. Before the blowpipe it does not fuse, but becomes of a varying tombac brown. It dissolves with the salt of phosphorus, but with difficulty; when it is powdered the solution takes place totally and readily; the pearl, which is coloured when hot, becomes colourless on cooling.

With borax the reaction of iron is evident; with soda there is lively effervescence; small white skeletons of silica float without dissolving in the interior of the pearl, which when cold is not transparent; with nitrate of cobalt a dirty gray colour is produced; when very finely levigated sismondine is completely acted upon by sulphuric, hydrochloric, and even by nitric acid, a white granular residue of silica is left, which is not dissolved by the acids; after calcination the action of the acids is not so easy.

By analysis it yielded-

$$
\begin{array}{lr}
\text { Silica ......... } & 24 \cdot 1 \\
\text { Alumina . . . . . } & 43 \cdot 2 \\
\text { Protoxide of iron. . } & 23.8 \\
\text { Water . . . . . } & 7 \cdot 6 \\
\text { Oxide of titanium } & \frac{\text { trace }}{98.7}
\end{array}
$$

Ann, de Ch. et de Phys., Decembre 1843.

\section{A METEOROLOGICAL PHANOMENON.}

About the middle of March 1843, an anthelion was observed on a cloud in the vicinity of Cork by Mr. H. Hennessy. 
Between four and five o'clock a.m., a faint image of the sun was perceived on the perpendicular side of a mass of clouds, called in Howard's nomenclature cumulo-stratus. These clouds were lying to the east of the observer. As the sun approached the horizon this image grew more distinct, and when the sun's altitude was about $15^{\circ}$ it reached its maximum of intensity. At this time rays of light were reflected from the anthelion on surrounding objects. Its apparent diameter seemed to be the same as that of the sun. At one period of its existence it was surrounded by a faint fringe of prismatic colours. The orange and red were more distinct than any of the other colours. The gray colour of the cloud rendered it impossible to trace the bluish tints of the fringe with any certainty. As the sun's altitude became less than $15^{\circ}$ the anthelion became less distinct, and soon afterwards entirely vanished.

Prospect Row, Cork, Feb. 9, 1844.

Henry Hennessy.

\section{METEOROLOGICAL OBSERVATIONS FOR JANUARY 1844.}

Chiswick.-January 1. Snow and sleet: clear and frosty at night. 2. Clear: sharp frost at night. 3. Severe frost: overcast: thawing rapidly. 4. Hazy : overcast. 5. Overcast : rain. 6, Mild and fine. 7. Exceedingly clear and fine : frosty. 8. Frosty : fine. 9. Thick haze : cold and dry : overcast. 10. Hazy : drizzly. 11, Overcast. 12. Foggy : heavy rain. 13. Slight drizzle : heavy clouds : squally, with rain. 14. Hazy and drizzly : clouds in strata: densely overcast. 15. Clear and frosty. 16. Sharp frost : very fine. 17, 18. Overcast. 19. Fine : densely clouded. 20. Cloudy, cold and dry. 21. Overcast. 22. Hazy: very fine. 23. Foggy : very fine, 24. Slight fog. 25. Frosty : very fine. 26. Very fine. 27. Slight rain. 28. Rain : fine. 29. Clear: overcast: squally. 30. Fine: showery. 31. Brisk wind, with small hail: stormy showers, snow, sleet, rain: densely overcast.-Mean temperature of the month $2 \frac{1}{2}^{\circ}$ above the average.

Boston.-Jan. 1. Cloudy : rain early A.M. 2, 3. Fine. 4, 5. Cloudy : rain early A.M. 6. Fine: rain early A.M. : rain P.M. 7. Cloudy. 8. Fine. 9. Cloudy : snow P.M. 10. Fine : rain P.M. 1, Cloudy, 12. Fine: rain P.M. 13. Cloudy : rain P.M. 14-16. Fine. 17. Cloudy. 18-20. Fine. 21. Cloudy : rain early A.M. 22. Cloudy. 23. Cloudy : rain early A.M. 24, 25. Foggy. 26. Fine. 27. Cloudy. 28. Cloudy: rain early $A_{0} M_{2}$ : rain P.M. 29. Fine. 30. Stormy. 31. Fine: stormy P.M.

Sandwick Manse, Orkney.-Jan. 1. Snow-showers. 2. Snow : bright : cloudy. 3. Snow-showers : clear. 4. Bright: frost : clear. 5. Rain. 6. Bright : rain. 7. Damp : clear. 8. Bright : clear. 9. Cloudy : rain. 10. Showers. 11. Bright : cloudy. 12. Rain : showers. 13. Bright: cloudy. 14. Frost : snow : clear. 15. Clondy. 16. Cloudy : drizzle 17. Drizzle. 18. Showers. 19. Hailshowers. 20. Snow-showers : cloudy, 21. Showers. 22. Bright : cloudy. 23. Drizzle, 24. Bright : fine. 25, 26. Showers. 27. Bright: drizzle. 28. Sleet-showers, 29. Rain: showers. 30. Sleet: showers. 31. Snow-drift : clear. Applegarth Manse, Dumfries-shire.-Jan. 1. Frost: snow-shower. 2. Frost, severe. 3. Thaw : rain p.M. 4. Small rain. 5, 6. Heavy rain. 7. Showers. 8. Frost. 9. Snow : rain P.M. 10. Frost. 11. Fog. 12. Small rain. 13. Frost : fair and fine. 14, 15. Frost : fine. 16. Slight frost. 17. Frost: fine. 18. Frost. 19. Showery. 20. Frost, slight. 21. Fair and elear. 22. Frost: fine. 23. Frost: mild. 24. Fair and mild. 25. Rain at noon, 26. Fair and fine. 27. Fair, but cloudy. 28. Shower, heavy. 29. Wet. 30. Rain : snow-shower. 31. Frost and snow.

Mean temperature of the month $38^{\circ} \cdot 4$

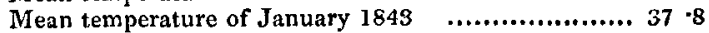

Mean temperature for twenty years .................... $34 \cdot 2$ 